Article

\title{
Preparation and catalytic performance of perfluorosulfonic acid-functionalized carbon nanotubes
}

\author{
Mengxiao Zhang, Cuican Li, Weiming Hua, Yinghong Yue*, Zi Gao \\ Department of Chemistry and Shanghai Key Laboratory of Molecular Catalysis and Innovative Material, Fudan University, Shanghai 200433, China
}

\section{A R T I C L E I N F O}

Article history:

Received 3 May 2014

Accepted 10 June 2014

Published 20 November 2014

\section{Keywords:}

Carbon nanotube

Perfluorosulfonic acid

Acidity

Stability

Hydroquinone alkylation

tert-butanol

\begin{abstract}
A B S T R A C T
Perfluorosulfonic acid-functionalized carbon nanotubes were prepared by liquid deposition of the perfluorosulfonic acid-polytetrafluoroethylene copolymer and characterized by $\mathrm{N}_{2}$ adsorption, scanning electron microscopy, transmission electron microscopy, Fourier transform infrared spectroscopy, and acid-base titration. The effects of reaction temperature and the type of solvent were investigated. The results showed that these solid acids are very stable in both polar and non-polar solvents and can maintain their acidity up to $300{ }^{\circ} \mathrm{C}$. Higher activity and better stability were observed over these materials in the alkylation of hydroquinone compared with poly(styrene sulfonic acid)-grafted carbon nanotubes.
\end{abstract}

(C) 2014, Dalian Institute of Chemical Physics, Chinese Academy of Sciences. Published by Elsevier B.V. All rights reserved.

\section{Introduction}

Acid-catalyzed reactions are the most important processes in fine chemical, pharmaceutical, and petrochemical industries. A significant number of acid-catalyzed reactions, such as the Friedel-Crafts reaction, esterification, hydration, and hydrolysis, are still carried out using liquid acids such as $\mathrm{H}_{2} \mathrm{SO}_{4}$ and $\mathrm{HF}$ as catalysts, leading to a series of problems such as the harmful effects on the environment, corrosion of apparatus, and difficulties in separating the reactants and products. Thus, there is a strong drive and major trend to replace these hazardous liquid acid catalysts with environmentally benign reusable solid acid materials, which provide much greener syntheses and processes [1]. In addition, many conventional solid acid catalysts lose their activity in water participating reactions because of the easy chemisorption of water on their active sites. Therefore, water-tolerant solid acid catalysts with high efficiency desperately need to be developed [2].

Carbonaceous materials functionalized with sulfonic acid groups have emerged as a promising solid acid material because of their inherent advantages of resistance to acidic and basic media and easily tunable properties [3-5]. Sulfonate-functionalized porous carbon-based solid acid materials can usually be prepared by direct sulfonation of ordered mesoporous carbon with sulfuric acid at elevated temperature [6,7], incomplete carbonization of sulfopolycyclic aromatic hydrocarbons [3], or sulfonation of incompletely carbonized organic compounds $[4,5]$. These materials have already exhibited high catalytic activity for various liquid-phase acid-catalyzed reactions, such as hydration of 2,3-dimethyl-2-butene, esterification of acetic acid, transesterification of triacetin, the Biginelli reaction, and oxidation of aldehydes to carboxylic ac-

\footnotetext{
* Corresponding author. Tel: +86-21-65642409; Fax: +86-21-65641740; E-mail: yhyue@fudan.edu.cn This work was supported by the National Natural Science Foundation of China (20773027, 20773028 and 21273043) and the Science \& Technology Commission of Shanghai Municipality (08DZ2270500).
} 
ids [5,8-10]. However, the stability of the resultant materials in the above cases is not satisfactory, especially in polar media, because of the leaching of polycyclic aromatic hydrocarbon-containing $-\mathrm{SO}_{3} \mathrm{H}$ groups [8,11]. In addition, a large amount of concentrated sulfuric acid is used in their preparation process, which is harmful to the environment. Furthermore, catalyst swelling is another important parameter that can remarkably affect the catalytic activity, indicating that sulfopolycyclic aromatic compounds are not suitable catalysts in non-media reactions (e.g., gas-phase reactions) [8].

Carbon nanotubes (CNTs) have attracted a lot of interest since their discovery in 1991 [12] because of their unique structural, mechanical, and electronic properties [13]. Because CNTs themselves have little catalytic activity, acidic functional groups need to be introduced, specifically onto the surface of CNTs, for their application to acid-catalyzed reactions. CNT-based acid catalysts have been synthesized by directly sulfonating CNTs [14-17], but the activity or the stability of the obtained catalysts was not ideal [14,17]. Sulfonated multiwalled carbon nanotubes have also been obtained by direct synthesis, resulting in higher stability [18]. CNT-based acid catalysts can also be synthesized by directly functionalizing CNTs with polymers. Poly(styrene sulfonic acid)-functionalized CNTs (PSA-CNTs) have been synthesized by in situ radical polymerization [19]. High activity and good stability can be achieved over this catalyst although the stability needs to be further improved [20].

In this work, perfluorosulfonic acid-functionalized CNT (PSFA-CNT) samples were prepared. Their textural, structural, and acidic properties were characterized by $\mathrm{N}_{2}$ adsorption, scanning electron microscopy (SEM), transmission electron microscopy (TEM), Fourier transform infrared spectroscopy (FTIR), thermogravimetric analysis (TGA), and titration methods. The catalytic activity and stability of the samples for alkylation of hydroquinone with tert-butanol were tested and compared with PSA-CNTs.

\section{Experimental}

\subsection{Catalyst preparation}

PFSA-CNT samples were synthesized by liquid deposition. Typically, $500 \mathrm{mg}$ of multi-walled carbon nanotubes (purity $>99.5 \%$, Chengdu Organic Chemical Co. Ltd.) was dispersed in a certain amount of PFSA-polytetrafluoroethylene (PTFE) copolymer solution ( $5 \mathrm{wt} \%$ solution, Alfa Aesar), and the mixture was then diluted with ethanol solution (75\%) until the total mass of the mixture was $25 \mathrm{~g}$. After sonication for $40 \mathrm{~min}$, the solution was stirring overnight at room temperature. The obtained black solid was then dried at $100^{\circ} \mathrm{C}$. The final product is designated as PFSA-CNT- $x$, where $x$ represents the mass ratio of the PFSA-PTFE copolymer to CNT.

\subsection{Catalyst characterization}

The $\mathrm{N}_{2}$ adsorption-desorption isotherms were measured on a Micromeritics ASAP 2000 instrument at liquid N2 tempera- ture. The specific surface areas of the samples were calculated from the adsorption isotherms by the Brunauer-Emmett-Teller (BET) method. FT-IR spectra of the samples were recorded on a Nicolet Avatar-360 spectrometer. TGA was performed using a PerkinElmer TGA7 instrument under a flowing $\mathrm{N}_{2}$ atmosphere at a heating rate of $10{ }^{\circ} \mathrm{C} / \mathrm{min}$. SEM studies were carried out with a Philips XL30 using an accelerating voltage of $15 \mathrm{kV}$. TEM images were taken using a JEOL JEM 2100 instrument. The sulfur content was measured by elemental analysis on a Bruker-AXS (S4 EXPLORER) elemental analyzer.

\subsection{Acidity measurement}

The density of surface acid sites was measured by a neutralization titration method [21]. In brief, the sample was added into an aqueous solution of $\mathrm{NaCl}$ (in excess), and $\mathrm{HCl}$ formed because of the exchange of $\mathrm{Na}^{+}$for protons on sulfonic groups, which were titrated with a standard solution of $\mathrm{NaOH}$. The acidity was also measured by potentiometric titration $[22,23]$. The solid was suspended in acetonitrile, agitated for $3 \mathrm{~h}$, and then titrated with 0.1 butylamine (mol/L) in acetonitrile. The electrode potential variation was recorded with a METTLER TOLEDO FE20 potentiometer.

\subsection{Catalytic testing}

Alkylation of hydroquinone was carried out in a stainless steel autoclave with a PTFE liner using magnetic stirring. Typically, $0.5 \mathrm{~g}$ hydroquinone, $1.0 \mathrm{~g}$ tert-butanol, and $0.2 \mathrm{~g}$ catalyst were added in the autoclave accompanied with $2 \mathrm{~g}$ xylene as solvent. The reaction lasted $4 \mathrm{~h}$. The products were analyzed with a GC122 gas chromatograph equipped with a SE-54 capillary column $(30 \mathrm{~m} \times 0.25 \mathrm{~mm} \times 0.3 \mu \mathrm{m})$ and a flame ionization detector.

\section{Results and discussion}

\subsection{Structure of the catalysts}

PFSA-CNT samples with different perfluorosulfonic acid loadings were prepared. Their $\mathrm{N}_{2}$ adsorption-desorption isotherms were recorded and are shown in Fig. 1. Similar isotherms were observed for all the samples, showing that modification by perfluorosulfonic acid has little effect on the pore structure of the CNTs.

Table 1 summarizes the textural properties of the prepared samples. The samples maintained a large surface area and pore volume after modification although slightly lower than that of the pristine CNTs.

The SEM images of the CNT materials before and after modification are shown in Fig. 2. Significant differences can be observed in the morphology of the CNTs before and after modification. The PFSA-CNTs are arranged in ordered sheets, while the pristine CNTs are disorganized and entwined without any order. A similar change was observed for PSA-CNTs [20].

The size and structure of the functionalized CNT materials can be determined by TEM (Fig. 3). It is clear from the TEM 


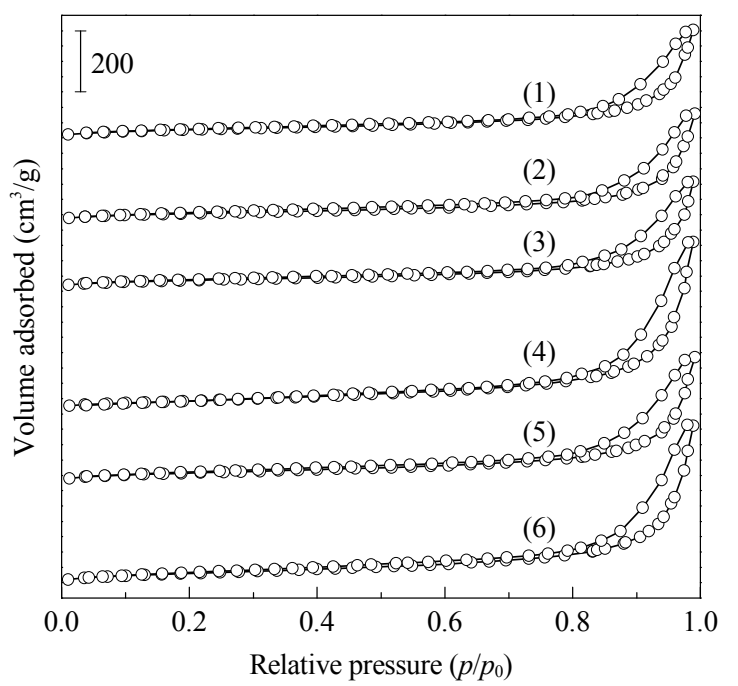

Fig. 1. $\mathrm{N}_{2}$ adsorption-desorption isotherms of (1) CNT, (2) PFSACNT-0.1, (3) PFSA-CNT-0.2, (4) PFSA-CNT-0.3, (5) PFSA-CNT-0.4, and (6) PFSA-CNT-0.5.

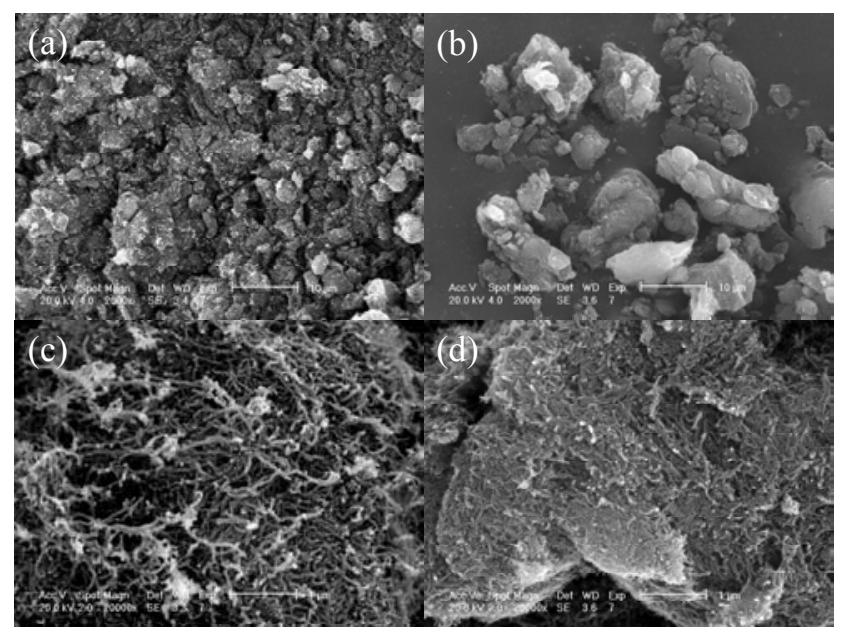

Fig. 2. SEM images of pristine CNT ((a) and (c)) and PFSA-CNT-0.3 ((b) and (d)).

images that polymer functionalization does not affect the tubular structure of the CNTs. The polymer was well deposited on the surface of the pore channels, which is in agreement with the results of the $\mathrm{N}_{2}$ adsorption measurements. These CNT materials have a nanodimension ranging from 20 to $30 \mathrm{~nm}$.

The thermal behavior of PFSA-CNT materials is shown in Fig. 4. A significant decrease in the mass percentage at $\sim 350{ }^{\circ} \mathrm{C}$ is observed, which can be attributed to the desorption or de-

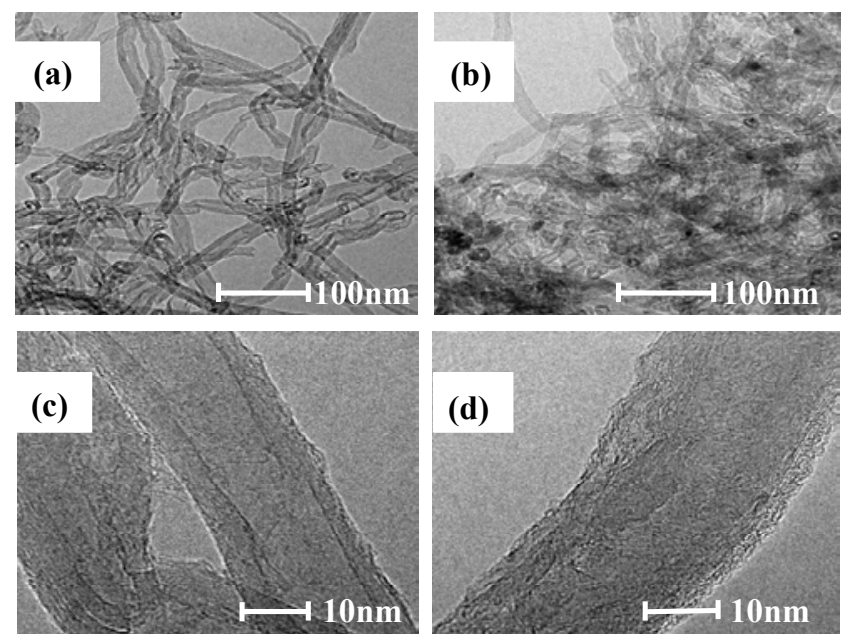

Fig. 3. TEM images of pristine CNT ((a) and (c)) and PFSA-CNT-0.3 ((b) and (d)).

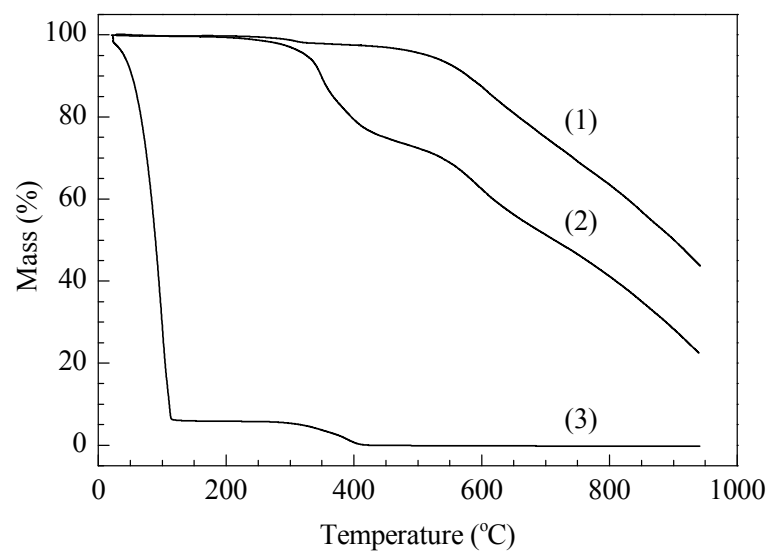

Fig. 4. TG curves of (1) pristine CNT, (2) PFSA-CNT-0.3, and (3) PFSAPTFE solution.

composition of the perfluorosulfonic acid functional group from the catalyst surface because the PFSA-PTFE copolymer shows a similar mass loss (the decrease at $50{ }^{\circ} \mathrm{C}$ is related to the desorption of solvent). The slow decrease in the mass percentage above $600{ }^{\circ} \mathrm{C}$ is because of the decomposition of the CNTs, which also occurs for the pristine CNT material.

Fig. 5 shows the FT-IR spectra of the CNT materials after polymer modification, together with that of PFSA-PTFE for comparison. The peaks at 620 and $1070 \mathrm{~cm}^{-1}$ confirmed the existence of the sulfonic group. All were consistent with FT-IR spectra of the pure PFSA-PTFE sample, suggesting the successful introduction of PFSA onto the surface of the CNTs.

Table 1

Textural and acidic properties of PFSA-CNT catalysts.

\begin{tabular}{lccccc}
\hline Sample & BET surface area $\left(\mathrm{m}^{2} / \mathrm{g}\right)$ & Pore volume $\left(\mathrm{cm}^{3} / \mathrm{g}\right)$ & Pore diameter $(\mathrm{nm})$ & Acid site amount ${ }^{\mathrm{a}}(\mathrm{mmol} / \mathrm{g})$ & $\mathrm{S} \mathrm{amount}{ }^{\mathrm{b}}(\mathrm{mmol} / \mathrm{g})$ \\
\hline CNT & 153 & 0.87 & 22.6 & - & - \\
PFSA-CNT-0.1 & 147 & 0.81 & 21.9 & 0.06 & 0.13 \\
PFSA-CNT-0.2 & 121 & 0.63 & 20.9 & 0.13 & 0.21 \\
PFSA-CNT-0.3 & 101 & 0.54 & 21.6 & 0.21. & 0.30 \\
PFSA-CNT-0.4 & 97 & 0.54 & 22.1 & 0.26 & 0.37 \\
PFSA-CNT-0.5 & 91 & 0.54 & 23.8 & 0.24 & 0.40 \\
\hline
\end{tabular}

a Obtained by neutralization titration. ${ }^{\mathrm{b}}$ Measured by XRF. 


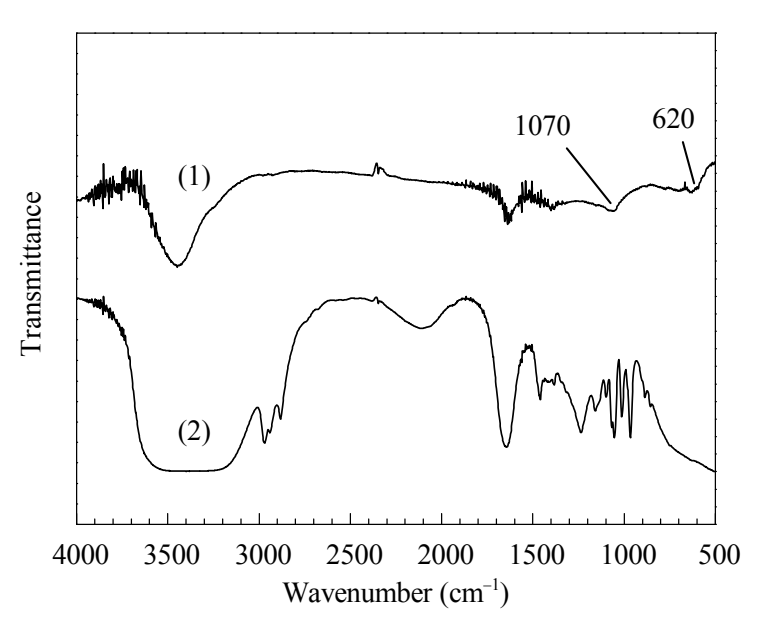

Fig. 5. FT-IR spectra of (1) PFSA-CNT and (2) PFSA-PTFE.

\subsection{Acidity of the catalysts}

The amount of acid sites on the PFSA-CNT samples was evaluated by neutralization titration, and the results are listed in Table 2. The amount of acid sites linearly increases with PFSA loading at the beginning, reaching a maximum at PFSACNT-0.4, and then deceases with further increase of PFSA loading, indicating that the deposited PFSA cannot be well dispersed at that time because of the limitation of the surface of the CNTs.

The acidity of the catalysts was also characterized by potentiometric titration with $n$-butylamine. The initial electrode potential indicates the maximum acid strength of the acid sites, and the amount of $n$-butylamine consumed, where the plateau is reached, indicates the total number of acid sites. The evaluated results are listed in Table 2, which are consistent with the results of neutralization titration.

The acid sites can be classified by their acid strength according to the following scale: $E>100 \mathrm{mV}$ (strong), $0 \mathrm{mV}<E<$ $100 \mathrm{mV}$ (medium), and $-100 \mathrm{mV}<E<0 \mathrm{mV}$ (weak) [22,23]. The increase in the total acid amount after modification was mainly caused by the increase of the acid sites with strong acid strength, which confirmed the strong acid strength of PFSA itself.

\subsection{Stability of the catalysts}

The thermal stability of the PFSA-CNT-0.3 sample was tested by calcining it at different temperatures for $4 \mathrm{~h}$. The results

Table 2

Acidity of PFSA-CNT catalysts obtained by potentiometric titration.

\begin{tabular}{lcccc}
\hline \multirow{2}{*}{ Sample } & \multicolumn{4}{c}{ Amount of acid sites (mmol/g) } \\
\cline { 2 - 5 } & Strong $^{\mathrm{a}}$ & Medium $^{\mathrm{b}}$ & Weak $^{\mathrm{c}}$ & Total \\
\hline PFSA-CNT-0.1 & 0.030 & 0.010 & 0.048 & 0.088 \\
PFSA-CNT-0.2 & 0.058 & 0.015 & 0.061 & 0.134 \\
PFSA-CNT-0.3 & 0.171 & 0.018 & 0.035 & 0.224 \\
PFSA-CNT-0.4 & 0.165 & 0.020 & 0.067 & 0.252 \\
PFSA-CNT-0.5 & 0.157 & 0.018 & 0.062 & 0.237 \\
\hline
\end{tabular}

${ }^{\mathrm{a}} E>100 \mathrm{mV} .{ }^{\mathrm{b}} 0 \mathrm{mV}<E<100 \mathrm{mV} \cdot{ }^{\mathrm{c}}-100 \mathrm{mV}<E<0 \mathrm{mV}$.

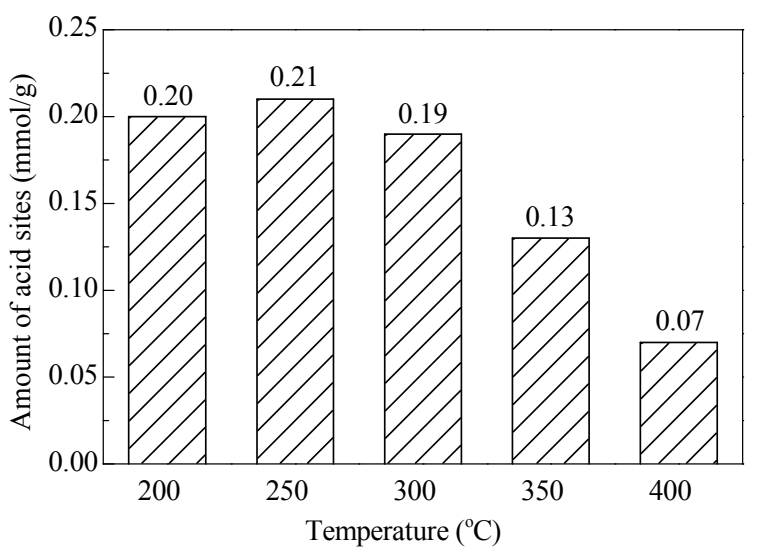

Fig. 6. Amount of acid sites on PFSA-CNT-0.3 after calcination at different temperatures.

are shown in Fig. 6. The amount of acid sites on the catalyst is almost unchanged after calcination at temperatures below 300 ${ }^{\circ} \mathrm{C}$ compared with the fresh sample. However, when the calcination temperature is $350{ }^{\circ} \mathrm{C}$ or above, a sharp decrease is observed. Almost no acidity is detected when the calcination temperature is $400{ }^{\circ} \mathrm{C}$. These results indicate that the temperature tolerance of the PFSA-CNT catalyst is less than $300{ }^{\circ} \mathrm{C}$, which is in agreement with the TG results shown in Fig. 4.

The stability of the catalyst in various solvents was also tested by treating the catalyst in the solvents at different temperatures. The results are summarized in Table 3. Little change in the acidity was observed at the reflux temperature of the solvents, showing that the catalyst is stable in both polar and non-polar solvents.

\subsection{Activity of the catalysts}

2-Tert-butylhydroquinone (2-TBHQ) is an excellent antioxidant that is widely used in food industry. It is conventionally prepared by the alkylation of hydroquinone with tert-butanol or isobutylene. The activity of PFSA-CNT for alkylation of hydroquinone was tested and compared with that of PSA-CNT, and the results are shown in Table 4. The activity of PFSA-CNT increases with PFSA loading and exceeds that of PSA-CNT when the content of copolymer reaches $x=0.4$. Because more acid sites were detected on PSA-CNT $(0.343 \mathrm{mmol} / \mathrm{g})$ than on PFSA-CNT-0.4 (0.252 mmol/g), the turnover frequency on PFSA-CNT is much higher.

However, the yield of TBHQ over PFSA-CNT is much lower than over PSA-CNT because of its low selectivity. More 2,5-DTBHQ and 2,5-DTBBQ were formed over PFSA-CNT than

\section{Table 3}

Acid site amount of PFSA-CNT-0.3 treated in various solvents obtained by neutralization titration.

\begin{tabular}{lccc}
\hline \multirow{2}{*}{ Temperature $\left({ }^{\circ} \mathrm{C}\right)$} & \multicolumn{3}{c}{ Acid site amount $(\mathrm{mmol} / \mathrm{g})$} \\
\cline { 2 - 4 } & Ethanol & Xylene & Water \\
\hline 75 & 0.20 & 0.20 & 0.20 \\
100 & 0.20 & 0.20 & 0.18 \\
125 & 0.19 & 0.19 & 0.18 \\
150 & - & 0.20 & - \\
\hline
\end{tabular}


Table 4

Catalytic activity of PFSA-CNTs for hydroquinone alkylation.

\begin{tabular}{|c|c|c|c|c|c|c|}
\hline \multirow{2}{*}{ Sample } & \multirow{2}{*}{ Conversion (\%) } & \multicolumn{4}{|c|}{ Selectivity (\%) } & \multirow{2}{*}{ Yield (\%) } \\
\hline & & 2-TBHQ ${ }^{\mathrm{a}}$ & 2,5-DTBHQb & 2,5-DTBBQ ${ }^{\mathrm{c}}$ & TBPE $^{d}$ & \\
\hline PFSA-CNT-0.1 & 47.9 & 41.3 & 12.6 & 18.3 & 23.7 & 19.8 \\
\hline PFSA-CNT- 0.2 & 56.6 & 43.5 & 25.4 & 16.4 & 14.2 & 24.6 \\
\hline PFSA-CNT- 0.3 & 66.5 & 39.8 & 34.6 & 14.3 & 10.9 & 26.4 \\
\hline PFSA-CNT-0.4 & 78.1 & 32.6 & 46.4 & 10.2 & 10.8 & 25.4 \\
\hline PFSA-CNT-0.5 & 87.5 & 27.4 & 58.4 & 9.01 & 5.26 & 24.0 \\
\hline PSA-CNT [23] & 73.3 & 73.2 & 17.2 & 4.2 & 5.6 & 53.7 \\
\hline
\end{tabular}

a 2-tert-butyl hydroquinone. ${ }^{\mathrm{b}}$ 2,5-di-tert-butyl hydroquinone. ${ }^{\mathrm{c}}$ 2,5-di-tert-butyl benzoquinone. ${ }^{\mathrm{d}}$ tert-butyl phenol ether.

PSA-CNT, which indicates that the acid strength of PFSA-CNT is stronger because the selectivity in this reaction is related to the acid strength of the catalyst. The higher acid strength causes the higher percentage of di-alkylation and oxidation products.

To confirm the heterogeneity of this catalytic reaction, a comparative experiment was carried out as follows: alkylation was performed for the first $2 \mathrm{~h}$ with PFSA-CNT and then for the second $2 \mathrm{~h}$ both with and without PFSA-CNT. The results shown in Fig. 7 indicate that the conversion did not obviously increase without the catalyst, suggesting that no leaching occurred during the reaction or the leaching species had negligible catalytic activity. Therefore, the alkylation catalyzed by PFSA-CNT catalyst under the present conditions is a heterogeneous catalytic reaction.

\subsection{Reusability of the catalysts}

The reusability of the PFSA-CNT catalyst was also tested After the reactions, the PFSA-CNT catalyst was filtered off, washed with ethanol, dried at $100{ }^{\circ} \mathrm{C}$, and then reused in the next reaction. The reaction data for the first three runs are

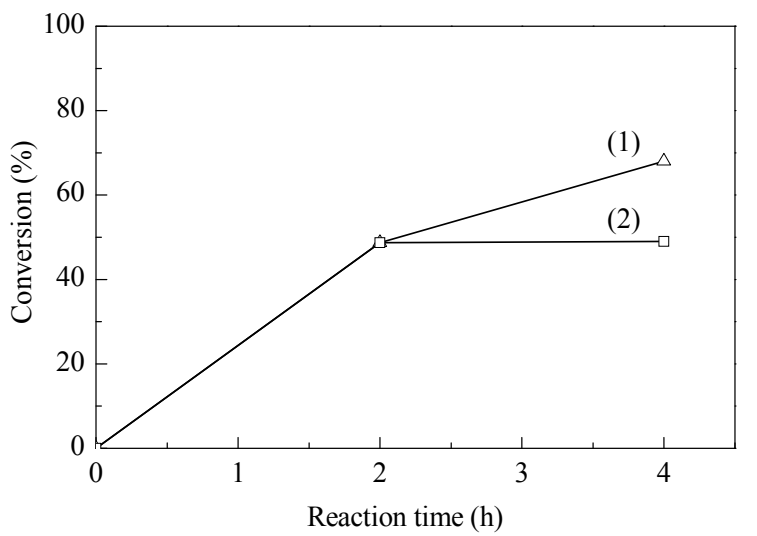

Fig. 7. Conversion of hydroquinone with (1) and without (2) the PFSA-CNT catalyst.

Table 5

Reusability of the PFSA-CNT- 0.3 catalyst.

\begin{tabular}{lcccccc}
\hline \multirow{2}{*}{ Run } & Conversion & \multicolumn{4}{c}{ Selectivity (\%) } & Yield \\
\cline { 3 - 6 } & $(\%)$ & 2-TBHQ & 2,5-DTBHQ & 2,5-DTBBQ & TBPE & $(\%)$ \\
\hline 1 & 66.5 & 39.8 & 34.6 & 14.3 & 10.9 & 26.4 \\
2 & 68.4 & 40.8 & 34.4 & 12.8 & 11.0 & 27.9 \\
3 & 66.1 & 38.4 & 34.1 & 15.6 & 11.1 & 25.4 \\
\hline
\end{tabular}

listed in Table 5. No noticeable deactivation was observed in these cycle processes. Compared with PSA-CNT and sulfonated carbon-based solid acid, whose hydroquinone conversions drop from $73.3 \%$ to $56.6 \%$ [20] and from $91 \%$ to $48 \%$ [11], respectively. After three runs under the same reaction conditions, the PFSA-CNT catalyst is much more stable and reusable. The enhanced stability may be caused by the higher stability of perfluorosulfonic group than the styrene sulfonic group.

\section{Conclusions}

Perfluorosulfonic acid-functionalized carbon nanotubes can be obtained by simply depositing the perfluorosulfonic acid-PTFE copolymer on the surface of CNTs. These materials are very stable in both polar and non-polar solvent and can maintain their acidity up to $300^{\circ} \mathrm{C}$. Higher activity and better stability were observed in the alkylation of hydroquinone with tert-butanol compared with poly(styrene sulfonic acid)-grafted carbon nanotubes. The catalyst can be reused after simply washing it with ethanol, and no obvious decrease of activity was observed using the recycled catalyst. The excellent catalytic behavior comes from the strong acid strength and high stability of the perfluorosulfonic group.

\section{References}

[1] Busca G. Chem Rev, 2007, 107: 5366

[2] Okuhara T. Chem Rev, 2002, 102: 3641

[3] Hara M, Yoshida T, Takagaki A, Takata T, Kondo J N, Hayashi S, Domen K. Angew Chem Int Ed, 2004, 43: 2955

[4] Toda M, Takagaki A, Okamura M, Kondo J N, Hayashi S, Domen K, Hara M. Nature, 2005, 438: 178

[5] Okamura M, Takagaki A, Toda M, Kondo J N, Domen K, Tatsumi T, Hara M, Hayashi S. Chem Mater, 2006, 18: 3039

[6] Chang B B, Fu J, Tian Y L, Dong X P.J Phys Chem C, 2013, 117: 6252

[7] Wang X Q, Liu R, Waje M M, Chen Z W, Yan Y S, Bozhilov K N, Feng P Y. Chem Mater, 2007, 19: 2395

[8] Mo X H, López D E, Suwannakarn K, Liu Y J, Lotero E, Goodwin J G Jr.J Catal, 2008, 254: 332

[9] Moghaddas M, Davoodnia A, Heravi M M, Tavakoli-Hoseini N. Chin JCatal (催化学报), 2012, 33: 706

[10] Zhou L P, Dong B B, Tang S, Ma H, Chen C, Yang X M, Xu J.J Energy Chem, 2013, 22: 659

[11] Zhou L N, Liu K, Hua W M, Yue Y H, Gao Z. Chin J Catal (周丽娜, 刘 可, 华伟明, 乐英红, 高滋. 催化学报), 2009, 30: 196

[12] Iijima S. Nature, 1991, 354: 56

[13] Pantarotto D, Partidos C D, Graff R, Hoebeke J, Briand J P, Prato M, 


\title{
Graphical Abstract
}

Chin. J. Catal., 2014, 35: 1874-1882 doi: 10.1016/S1872-2067(14)60167-4

\section{Preparation and catalytic performance of perfluorosulfonic acid-functionalized carbon nanotubes}

Mengxiao Zhang, Cuican Li, Weiming Hua, Yinghong Yue*, Zi Gao Fudan University
Perfluorosulfonic acid-functionalized carbon nanotubes were prepared and exhibit higher activity and better stability in the alkylation of hydroquinone than poly(styrene sulfonic acid)-functionalized carbon nanotubes.

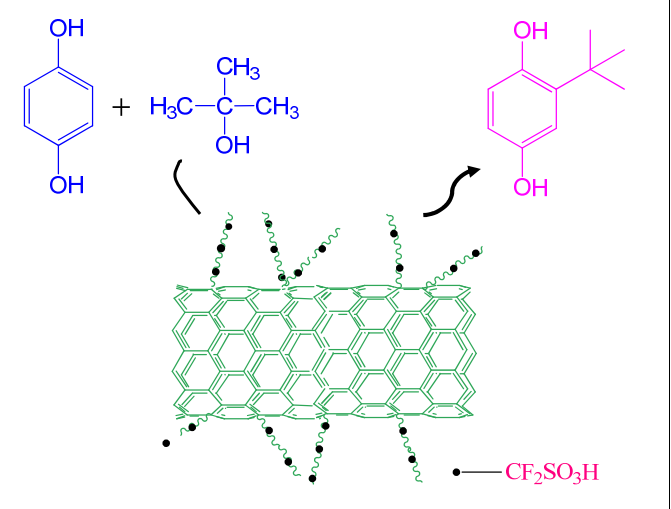

Bianco A. J Am Chem Soc, 2003, 125: 6160

[14] Peng F, Zhang L, Wang H J, Lü P, Yu H. Carbon, 2005, 43: 2405

[15] Shu Q Zhang Q, Xu G H, Wang J F. Food Bioprod Process, 2009, 87: 164

[16] Yu H, Jin Y G, Li Z L, Peng F, Wang H J. J Solid State Chem, 2008, 181: 432

[17] Poonjarernsilp C, Sano N, Tamon H. Appl Catal B, 2014, 147: 726

[18] Doroodmand M M, Sobhani S, Ashoori A. Can J Chem, 2012, 90: 701
[19] Zhang X H, Tang Q Q, Yang D, Hua W M, Yue Y H, Wang B D, Zhang X H, Hu J H. Mater Chem Phys, 2011, 126: 310

[20] Liu K, Li C C, Zhang X H, Hua W M, Yang D, Hu J H, Yue Y H, Gao Z. Catal Commun, 2010, 12: 217

[21] Benak K R, Dominguez L, Economy J, Mangun C L. Carbon, 2002, 40: 2323

[22] Cid R, Pecchi G. Appl Catal, 1985, 14: 15

[23] Khder A S, El-Sharkamy E A, El-Hakam S A, Ahamed A I. Catal Commun, 2008, 9: 769

\section{全氟磺酸功能化碳纳米管的制备及其催化性能}

\author{
张梦晓, 李璀灿, 华伟明, 乐英红 ${ }^{*}$, 高 滋 \\ 复旦大学化学系, 上海市分子催化和功能材料重点实验室, 上海200433
}

\begin{abstract}
摘要: 采用全氟磺酸-全氟乙烯共聚物的液相沉积方法制备了全氟磺酸功能化碳纳米管催化剂, 利用 $\mathrm{N}_{2}$ 吸附、扫描电子显微镜、 透射电子显微镜、傅里叶变换红外光谱以及酸碱滴定等方法对材料的结构和酸性进行了表征, 考察了温度和溶剂对催化剂稳定性 的影响. 结果表明, 催化剂在极性和非极性溶液中均十分稳定, 并且具有良好的热稳定性, 使用温度可达 $300{ }^{\circ} \mathrm{C}$. 该催化剂在对苯 二酚与叔丁醇的烷基化反应中表现出优异的催化性能, 其催化活性与稳定性均高于聚苯乙烯磺酸功能化的碳纳米管催化剂.
\end{abstract}

关键词: 碳纳米管; 全氟磺酸; 酸性; 稳定性; 对苯二酚; 叔丁醇; 烷基化反应

收稿日期: 2014-05-03. 接受日期: 2014-06-10. 出版日期: 2014-11-20.

*通讯联系人. 电话: (021)65642409; 传真: (021)65641740; 电子信箱: yhyue@fudan.edu.cn 基金来源：国家自然科学基金(20773027, 20773028和21273043); 上海市科学技术委员会(08DZ2270500).

本文的英文电子版由Elsevier出版社在ScienceDirect上出版(http://www.sciencedirect.com/science/journal/18722067).

\section{1. 前言}

酸催化反应是化工领域中最重要的反应. 然而, 在 许多传统的工业生产中, 诸如水解、水合、酯化和FriedelCrafts 反应等, 还经常使用包括硫酸和氢氟酸在内的液 体酸作为催化剂. 这类酸催化剂在实际使用时存在许多 问题：其强腐蚀性容易对生产设备造成破坏；其废液会 造成环境污染; 催化剂与原料和产物不易分离等. 用固 体酸作为催化剂可以很好地解决这些问题, 因此开发新 型绿色固体酸催化材料是目前化学工业的当务之急 ${ }^{[1]}$.
如今已有不少固体酸催化剂被应用于工业生产, 如以各 种沸石分子笚为催化剂的催化裂解、二甲苯异构化和甲 苯歧化等反应, 以固体超强酸为催化剂的 $\mathrm{C}_{5} / \mathrm{C}_{6}$ 异构化反 应等. 然而, 对于有水参与的液相反应, 固体酸成功的例 子较少, 主要原因是传统的固体酸催化剂容易在有水存 在的环境中失活, 因此亟需开发新型高效不怕水的固体 酸催化剂[2].

碳基磺酸化固体酸作为一类有前景的固体酸催化 剂具有诸多优异的性质, 该类催化剂不怕水, 在酸、碱介 质中十分稳定, 表面性质可调 ${ }^{[3-5]}$. 通常情况下碳基磺酸 
化固体酸可以通过高温下直接磺酸化有序介孔碳材 料 ${ }^{[6,7]}$ 或对含磺酸基团的稠环化合物进行不完全碳化来 制备 ${ }^{[3]}$, 也可以将有机化合物材料进行不完全碳化后再 磺酸化得到 ${ }^{[4,5]}$. 这些催化剂已被应用于一些液相催化 反应中, 如2,3-二甲基-2-丁烯水合反应、乙酸酯化反应、 三乙酸甘油酯酯交换反应、biginelli反应以及醛氧化制 羧酸的反应, 并且表现出优良的催化性能 ${ }^{[5,8-10]}$. 然而这 些催化剂的稳定性还不尽如人意, 尤其是在高温极性介 质中, 催化剂表面的- $\mathrm{SO}_{3} \mathrm{H}$ 基团容易脱落 ${ }^{[8,11]}$. 催化剂制 备过程中大量硫酸的使用也会造成一定的环境污染. 同 时, 此类催化剂的活性与溶胀效应密切相关, 因此这类 碳基磺酸化固体酸不适用于无溶剂存在的气相反应体 系 ${ }^{[8]}$.

碳纳米管自 1991年被Iijima ${ }^{[12]}$ 发现以来, 由于其独 特的结构、优异的物理化学特性、较大的表面积和易于 修饰的表面性质, 受到了广泛关注 ${ }^{[13]}$. 碳纳米管本身不 具备酸催化性能, 要使其在催化领域得到应用必须在其 表面修饰上酸性基团. 将碳纳米管直接磺酸化制得的碳 基固体酸 ${ }^{[14-17]}$, 其酸性和稳定性并不理想 ${ }^{[14,17]}$, 而采用 直接合成法制备的磺酸化多壁碳纳米管具有更好的稳 定性 ${ }^{[18]}$. 我们课题组 ${ }^{[19]}$ 提出了利用高分子聚合物对碳 纳米管进行功能化, 并且成功地利用原位聚合法制备得 到了聚苯乙烯磺酸功能化的碳纳米管催化剂(PSACNT). 该催化剂具有较高的酸量和较好的催化性能, 但 是其稳定性仍需进一步改进 ${ }^{[20]}$.

本文制备了一系列修饰量不同的全氟磺酸功能化 碳纳米管催化剂, 利用 $\mathrm{N}_{2}$ 吸附、扫描电子显微镜、透射 电子显微镜、红外光谱、热重分析、电位滴定和酸碱中 和滴定等方法对催化剂的结构和酸性进行了表征, 考察 了催化剂在对苯二酚与叔丁醇的烷基化反应中的催化 活性和稳定性, 并与聚苯乙烯磺酸功能化的碳纳米管催 化剂(PSA-CNT)进行了比较.

\section{2. 实验部分}

\section{1. 催化剂的制备}

全氟磺酸功能化碳纳米管通过液相沉积法制备. 将 $500 \mathrm{mg}$ 多壁碳纳米管(成都有机化学有限公司产品, 纯 度 $>95 \%$ )加入到一定量的 $5 \mathrm{wt} \%$ 全氟磺酸-全氟乙烯共 聚物的杂醇溶液(Alfa Aesar产品)中, 用75\%乙醇稀释至 $25 \mathrm{~g}$, 以低能超声处理 $40 \mathrm{~min}$ 使碳纳米管分散均匀后, 再 电磁搅拌过夜. 将得到的黑色块状物放入 $100^{\circ} \mathrm{C}$ 的烘 箱中过夜. 所得材料记为PFSA-CNT $-x$, 其中 $x$ 是指全氟
磺酸-全氟乙烯共聚物与多壁碳纳米管的质量比.

\section{2. 催化剂的结构表征}

用美国麦克公司的ASAP-2000型自动吸附分析仪 测定样品的 $\mathrm{N}_{2}$ 吸附等温线, 比表面积由BET方法得到, 孔径和孔体积利用 $\mathrm{BJH}$ 方法算得. 用美国尼高力 (Nicolet)公司Avatar-360型傅里叶红外光谱仪采集样品 的红外光谱. 用美国珀金埃尔默 (PerkinElmer) 公司 TGA7型热重分析仪分析样品的热稳定性, $\mathrm{N}_{2}$ 气氛, 升温 速率 $10^{\circ} \mathrm{C} / \mathrm{min}$. 用荷兰Philips公司XL30型扫描电镜观 察样品形貌. 用日本电子公司JEM 2100 型透射电子显 微镜观察样品的特征结构和形貌. 用德国Bruker-AXS 公司S4 EXPLORER型X射线荧光光谱测定 $\mathrm{S}$ 含量.

\section{3. 催化剂的酸性表征}

催化剂表面酸量通过酸碱中和滴定方法测定 ${ }^{[21]}$, 将 $0.1 \mathrm{~g}$ 催化剂加入到 $30 \mathrm{~mL} \mathrm{NaCl}$ 溶液 $(2 \mathrm{~mol} / \mathrm{L})$ 中, 室温下 搅拌 $3 \mathrm{~d}$, 使催化剂表面 $\mathrm{H}^{+}$离子和 $\mathrm{Na}^{+}$离子交换达到平衡. 催化剂过滤之后, 清液用 $\mathrm{NaOH}$ 溶液 $(10 \mathrm{mmol} / \mathrm{L})$ 滴定. 表面酸量还通过电位滴定法测定 ${ }^{[22,23]}$, 即将催化剂加入 到一定量乙腈中, 搅拌 $3 \mathrm{~h}$, 然后用正丁胺的乙腈溶液 $(0.1 \mathrm{~mol} / \mathrm{L})$ 滴定, 电位变化用Mettler Toledo FE20型 $\mathrm{pH}$ 计 (梅特勒-托利多国际贸易(上海)有限公司)测定.

\section{4. 催化性能的测试}

对苯二酚与叔丁醇烷基化反应在内祄有聚四氟乙 烯的不锈钢高压釜中进行, 使用磁力搅拌并通过油浴控 制反应温度. 反应条件如下：对苯二酚 $0.5 \mathrm{~g}$, 叔丁醇 1.0 $\mathrm{g}$, 二甲苯 $2.0 \mathrm{~g}$ 作为溶剂, 催化剂 $0.20 \mathrm{~g}$, 在 $150{ }^{\circ} \mathrm{C}$ 反应 4 h. 产物使用配有SE-30毛细管色谱柱 $(30 \mathrm{~m} \times 0.25 \mathrm{~mm} \times$ $0.3 \mu \mathrm{m})$ 的 $\mathrm{GC} 122$ 型气相色谱仪分析.

\section{3. 结果与讨论}

\section{1. 催化剂的结构}

制备了一系列修饰量不同的全氟磺酸功能化碳纳 米管催化剂. 图1为功能化前后样品的 $\mathrm{N}_{2}$ 吸附-脱附等温 线. 可以发现, 样品等温线的形状非常相似, 说明全氟磺 酸-全氟乙烯的修饰对碳纳米管本身结构的影响很小.

表1列出了上述样品的比表面积、孔体积和平均孔 径. 碳纳米管的比表面为 $153 \mathrm{~m}^{2} / \mathrm{g}$, 孔体积为 $0.87 \mathrm{~cm}^{3} / \mathrm{g}$. 与碳纳米管相比, 全氟磺酸-全氟乙烯修饰后样品的比 表面积和孔体积有所下降, 考虑到样品中碳纳米管的实 际含量, 比表面积下降的程度并不大.

图2给出了碳纳米管和功能化碳纳米管的SEM照片. 可以看出, 功能化后碳纳米管的聚集形式发生了明显变 
化. 高分子修饰前碳纳米管无规则地缠绕在一起, 呈现 出杂乱无章的状态, 但在修饰之后, PFSA-CNT总体呈片 状, 单根碳纳米管之间的排列也表现出一定的方向性, 这与聚苯乙烯磺酸功能化的碳纳米管(PSA-CNT)的情 况十分相似 ${ }^{[20]}$.

图3为碳纳米管和功能化碳纳米管的 TEM照片. 可 以看到, 功能化后碳纳米管的管状结构没有改变. 聚合 物在碳纳米管表面分散良好. 这也与上述 $\mathrm{N}_{2}$ 吸附表征结 果一致. 同时也可以看到, 功能化碳纳米管样品的管径 为 20-30 nm, 比修饰之前有所增加.

图4给出了碳纳米管、功能化碳纳米管和全氟磺酸全氟乙烯聚合物 (5 wt \% 杂醇溶液)的热重曲线. 可以看 到, 聚合物本身(曲线(3))在 $350{ }^{\circ} \mathrm{C}$ 有一个明显的失重, 这 是磺酸基团的脱除或分解所致 $\left(50^{\circ} \mathrm{C}\right.$ 处失重是溶剂挥发 造成的). 样品PFSA-CNT的热重曲线(2)在 $350{ }^{\circ} \mathrm{C}$ 也有同 样的趋势, 表明修饰后全氟磺酸基团的稳定性与修饰前 相同, 而温度高于 $600{ }^{\circ} \mathrm{C}$ 时的缓慢失重为碳纳米管的失 重, 这在碳纳米管的失重曲线(1)上也可以观察到.

将功能化碳纳米管以及全氟磺酸-全氟乙烯的红外 光谱作了对比, 结果见图5. 从PFSA-CNT的光谱图上可 以看到, 在 620 和 $1070 \mathrm{~cm}^{-1}$ 处出现了磺酸基的特征峰, 说 明全氟磺酸基团被成功引入到碳纳米管表面.

\section{2. 催化剂的酸性}

利用酸碱滴定测试了样品的酸量, 结果见表1. 随着 全氟磺酸-全氟乙烯修饰量的增加, 样品的酸量几乎线 性增加, 样品PFSA-CNT-0.4的酸量最高. 继续增加修饰 剂量, 催化剂的酸量并未增大. 这可能是由于碳纳米管 比表面积较小, 使得过量的全氟磺酸-全氟乙烯不能很 好地分散到碳纳米管表面.

为了同时考察催化剂的酸强度和酸量, 我们采用电 位滴定法对样品进行了表征, 样品总酸性位数目由正丁 胺的消耗量得到. 按照文献建议 ${ }^{[22,23]}$, 我们指定电位超 过 $100 \mathrm{mV}$ 的酸性位为强酸位, $0-100 \mathrm{mV}$ 为中强酸位, $-100-0 \mathrm{mV}$ 为弱酸位, 得到的结果列于表 2 . 电位滴定得 到的数据与酸碱滴定的结果基本一致. 另外, 修饰剂量 增加造成的样品总酸性位数目的增加主要来自强酸酸 性位 $(E>100 \mathrm{mV})$ 的增加, 这也验证了全氟磺酸-全氟乙 烯自身的强酸性.

\section{3. 催化剂的稳定性}

以PFSA-CNT-0.3为代表测试了全氟磺酸功能化碳 纳米管的热稳定性. 将样品在不同温度下焙烧 $4 \mathrm{~h}$ 后测 试其酸量, 并与焙烧前的样品进行对比, 结果如图6所示.
在 $300{ }^{\circ} \mathrm{C}$ 以下焙烧的样品酸量未出现变化, 当焙烧温度 超过 $300{ }^{\circ} \mathrm{C}$ 时, 样品酸量大幅下降; 而当焙烧温度达到 $400{ }^{\circ} \mathrm{C}$ 时, 样品已基本没有酸性. 结果表明, 催化剂的适 用温度不宜超过 $300^{\circ} \mathrm{C}$, 这也与图4热重分析结果相一 致.

为了进一步探讨催化剂的适用范围, 我们还考察了 上述样品在不同温度下不同溶剂中的溶脱性能. 将 $0.1 \mathrm{~g}$ 催化剂加入到 $10 \mathrm{~mL}$ 溶剂中, 在不同温度下加热搅拌 $4 \mathrm{~h}$, 随后离心过滤, 干燥后的催化剂用中和滴定方法测其表 面酸量, 结果列于表3. 该样品在三种溶剂中不同回流温 度下处理后酸量均未出现明显下降, 说明该催化剂在极 性和非极性溶液中均十分稳定.

\section{4. 催化剂的催化性能}

2-叔丁基对苯二酚(TBHQ)具有良好的抗氧化性能, 其作为防腐剂广泛应用在食品行业中. 传统的制备方法 是通过对苯二酚与叔丁醇烷基化反应. 表 4 列出了 PFSA-CNT催化剂对上述烷基化反应的催化性能, 并与 PSA-CNT催化剂进行对比. 结果表明, PFSA-CNT催化 剂的活性随着全氟磺酸-全氟乙烯修饰量的增加而增大. 当聚合物与碳纳米管的质量比达到 0.4 时, 其活性超过了 PSA-CNT催化剂. 由于PFSA-CNT-0.4催化剂的酸量为 $0.252 \mathrm{mmol} / \mathrm{g}$, 低于PSA-CNT的酸量 $(0.343 \mathrm{mmol} / \mathrm{g})$, 说明 PFSA-CNT催化剂的TOF值更高.

同时, 以PFSA-CNT为催化剂时, 目的产物TBHQ选 择性较低, 反应生成了更多的2,5-DTBHQ和2,5-DTBBQ 副产物. 这是由于上述反应的选择性与催化剂的酸强度 密切相关, PFSA-CNT催化剂的酸强度过高, 从而导致二 烷基化产物(2,5-DTBHQ)和氧化产物(2,5-DTBBQ)等副 产物的大量生成.

在液相反应中, 固体催化剂活性中心容易脱落到溶 液中, 使反应过程存在均相催化的可能. 为了验证反应 的多相性, 设计了一个对比实验. 烷基化反应在催化剂 存在下进行 $2 \mathrm{~h}$, 再离心过滤去掉催化剂后继续反应 2 $\mathrm{h}$, 结果见图7. 可以发现, 除去催化剂后, 对苯二酚的转 化率几乎保持不变, 这证明PFSA-CNT催化剂催化的烷 基化反应确实为多相催化反应. 即使反应过程中有少量磺 酸基团脱落, 在反应溶液中也起不到催化作用.

\section{5. 催化剂重复使用性能}

以PFSA-CNT-0.3为代表, 考察了催化剂的重复使用 性能. 催化剂在反应后, 经过滤, 用乙醇洗涤, 于 $100{ }^{\circ} \mathrm{C}$ 干 燥过夜后, 直接用于下一次反应, 反应结果列于表 5 . 在 3 次循环反应中, 样品PFSA-CNT-0.3没有出现明显失活; 
而在相同反应条件下, PSA-CNT经3次循环后对苯二酚 转化率从 $73.3 \%$ 下降到 $56.6 \%{ }^{[20]}$, 磺酸化的碳基固体酸上 的转化率则从 $91 \%$ 下降到 $48 \%{ }^{[11]}$. 这说明样品 PFSA-CNT更加稳定, 具有极好的重复使用性. 这是由 于全氟磺酸的稳定性高于对苯乙烯磺酸钠, 从而使样品 PFSA-CNT的稳定性优于PSA-CNT.

\section{4. 结论}

通过液相沉积方法制备的全氟磺酸功能化的碳纳
米管催化剂在极性和非极性溶剂中均可以保持稳定, 热 稳定性可以达到 $300{ }^{\circ} \mathrm{C}$. 与聚苯乙烯磺酸功能化的碳纳 米管催化剂相比, 该催化剂具有更高的酸催化能力, 含 有 $0.25 \mathrm{mmol} / \mathrm{g}$ 酸量的催化剂在烷基化反应中活性就超 过了 $0.34 \mathrm{mmol} / \mathrm{g}$ 酸量的聚苯乙烯磺酸功能化的碳纳米 管催化剂. 催化剂具有很好的重复使用性能, 通过洗涤 即可直接用于下一次反应, 反应 3 次后活性几乎不变. 该 催化剂优异的催化性能来源于高酸强度和稳定的全氟 磺酸基团. 